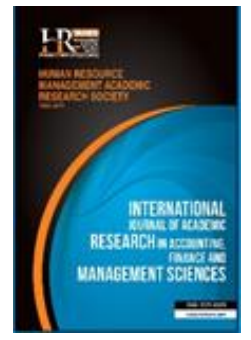

International Journal of Academic Research in Accounting, Finance and Management Sciences

Vol. 8, No.3, July 2018, pp. 73-82

E-ISSN: 2225-8329, P-ISSN: 2308-0337

(c) 2018 HRMARS

www.hrmars.com

To cite this article: Ejike, S.I., Agha, N.C. (2018). Impact of Operating Liquidity on Profitability of Pharmaceutical Firms in Nigeria, International Journal of Academic Research in Accounting, Finance and Management Sciences 8

\title{
Impact of Operating Liquidity on Profitability of Pharmaceutical Firms in
}

\author{
Sylvester Ikechukwu EJIKE ${ }^{1}$, Nancy C. AGHA \\ Accountancy Dept., Enugu State University of Science \& Technology (ESUT) Enugu, and \\ Accountancy Dept., Institute of Management \& Technology (IMT) Enugu, ${ }^{1}$ E-mail: ejike30@gmail.com \\ ${ }^{2}$ Ebonyi State University, Abakaliki, Nigeria, ${ }^{2}$ E-mail: nancyagha@gmail.com
}

\begin{abstract}
Operating liquidity involves the most liquid resources of the firm which includes cash and cash equivalents, inventories, trade debtors and other receivables. Most firms do not ensure optimal level of operating liquidity and this has been a major obstacle to their overall profitability. The study examined the impact of operating liquidity on the profitability of Pharmaceutical firms listed on the Nigerian Stock Exchange. Correlation and expost facto research design were used in a sample of 5 Pharmaceutical firms. Secondary data for a period of 10 years (2002-2011) was used, and Ordinary Least Squares (OLS) multiple regression was employed in data analysis. The study found that operating liquidity (account receivables collection, accounts payables management) has a significant impact on the profitability of listed pharmaceutical firms in Nigeria. It is therefore recommended among others that managers should, collect receivable as soon as possible because it is better to receive inflows sooner than later, and delay payment of creditors in order to invest the money in short-term securities which are profitable.

Key words Operating liquidity, profitability, pharmaceutical Firms

Received: 1 Aug $2018 \quad$ (C) The Authors 2018

Revised: 15 Aug 2018 Published by Human Resource Management Academic Research Society (www.hrmars.com)

Accepted: $\quad 28$ Aug 2018 This article is published under the Creative Commons Attribution (CC BY 4.0) license. Anyone may Published Online: 4 Sept 2018 reproduce, distribute, translate and create derivative works of this article (for both commercial and noncommercial purposes), subject to full attribution to the original publication and authors. The full terms of this license may be seen at: http://creativecommons.org/licences/by/4.0/legalcode
\end{abstract}

\section{Introduction}

The economic theory of firm requires that firm resources should be utilized efficiently in order to achieve economic successes. Moreover, the competitive modern business environment makes financial managers irrespective of the nature of their business to ensure efficient utilization of firm resources. Firm resources are broadly classified into two, long term assets (non-current assets) and short-term assets (current assets). Therefore, there are two major decisions in the theory of corporate financial management, that is, the long-term or capital budgeting decision and the short-term or working capital management decision (Pandey, 2009). Although long-term capital decisions are of critical importance to the going concern of a firm, efficient operating liquidity has direct consequences on the liquidity position and the ultimate profitability of a firm (Burt and Abbate, 2009).

Operating liquidity connotes the funds lock up in materials, work in progress, finished goods, receivables and cash. In this regard, Khan and Jain, (2005) state that current assets are those assets, which can be converted into cash within a short period of time, and the cash received is again invested into these assets; hence, it is constantly receiving or circulating. Therefore, operating liquidity is one of the most important measurements of the financial position, which according to Guthmann (2008) is the life-blood and nerve center of any business entity. This necessitated the need for the careful management of operating liquidity in every business organization with the value maximization objective. 
Therefore, operating liquidity management involves the application of strategies and policies in the use of firm's current assets and liabilities in such a way that an optimum level of working capital is maintained. In essence, the goal of operating liquidity management is to promote a satisfying profitability and maximizes shareholders' value ( $\mathrm{Li}$ and Han-Wen, 2006). They further lament that profitability is affected by the choices that companies make regarding their operating liquidity policies. Thus, if a firm cannot maintain an optimum level of working capital or operating liquidity, it is likely to become insolvent and may even be forced into bankruptcy, however, the need for working capital to run day-to-day business activities effectively.

In essence, managing operating liquidity is necessary because of its' direct effects on the profitability and liquidity of a corporate entity. Rehn (2012) asserts that operating liquidity usually refer to net working capital, the difference between current assets and current liabilities. Thus, it involves minimizing the timing of collecting receivables, deferring the period of payables, and keeping the minimal inventory. Moreover, operating liquidity management includes cash management, that is, how to invest idle cash without compromising liquidity.

Consequently, extant literature on firm profitability and efficiency documents different resulting effect of sub-optimal operating liquidity management on performance and value of firm (Deloof, 2003). According to him, efficient operating liquidity have many effects, which include speeds payment of shortterm commitments on firms; facilitating owner financing and it reduces working capital as a cause of firms' failure. In addition, Osisioma, (1997) and Wignaraja and O'Neil (1999) revealed that a good operating liquidity ensures a sound liquidity for assurance of long-term economic growth and attainment of profit generating process, and also ensures acceptable relationship between the components of firms' operating liquidity for efficient mix which guarantee capital adequacy. On the contrary, Peel and Wilson (1996), Shin and Soenen (1998), Eljielly (2004) and Appuhami (2008) are of the view that inefficient operating liquidity induces firms' failures, overtrading signs, inability to propel firm liquidity and profitability, and loss of business due to scarcity of products. However, optimal efficient operating liquidity management is usually achieved through the management of receivables, payables, inventory, cash conversion cycle and the operating cycle as a whole. In this regards, Van Horne (1995) laments that accounts receivables management involves achieving an optimal average time taken by credit customers to settle their accounts. Moreover, since the purpose of offering credit is to maximize profitability, the costs of debt collection should not be allowed to exceed the amounts recovered. Accounts or trade payables management focuses on the average time taken by a company to pay its trade payables (suppliers); it the current liabilities and all obligations, which mature within a year such as creditors, bills payable, accrued expenses, short-term bank loan, income tax liability and long-term debt excluding bank overdraft, all of which quickly mature in the current year (Uyar, 2009).

Moreover, accounts payables management is used to know how much credit time received by the firm from its trade creditors; it therefore shows the breathing time received by the firm in terms of payment of credit purchase. Hence, the effectiveness lies in whether the firm is enjoying the actual credit period promised by suppliers. Cash conversion cycle according to Wang (2002) is used in measuring cash management, and it represents the interaction between the components of working capital and the flow of cash within a company. Similarly, it can also be used to determine the amount of cash needed for any sales level; it is therefore a period of time between the outlay of cash on raw materials and the inflow of cash from the sale of finished goods.

In view of the foregoing discussions, operating liquidity is considered a very sensitive area in the field of financial management (Joshi, 1994); because it involves the decision of the amount and composition of current assets and the financing of these assets. Moreover, the decisions with regards the level of different working capital components become frequent, repetitive, and time consuming. However, most firms do not hold the correct amount of working capital and this has been a major obstacle to their overall profitability (Stephen, 2012). This together with the current liquidity crisis has highlighted the significance of working capital management. Because management of working capital has profitability and liquidity implications, which requires the firm manager to reach optimal working capital by controlling the trade-off between profitability maximization and liquidity accurately (Raheman and Mohamed, 2007). 
This study is motivated by the recent global financial crises which significantly affect the liquidity position and the overall business activities across the world. In Nigeria, where credit is either not available or expensive to obtain, there are corporate issues across almost all the firms that, has to do with liquidity problem and consequently their operating performance. Financial managers are always expected when there is a liquidity problem, to examine the current assets and current liabilities in order to make an informed decision with regard the profitability of their entity. In the same vein, researchers do conduct studies to examine the relationships among the firms' working capital components and profitability using different methodologies. Therefore, this study focuses on pharmaceutical companies in Nigeria; the pharmaceutical industry manufactures and distributes drugs and medical equipment to the Nigerian populace. Nigeria as an African nation with over 140 million citizens is known with high demand of drugs and adequate health care services to address medical problems. Despite the high demand of pharmaceutical business in Nigeria, the market is described as one of the smallest among Middle and East African (MEA) region (Lead Capital Limited, 2008). With the exception of a few globally recognized brands, many of the pharmaceutical companies and health care providers in Nigeria cannot adequately compete internationally (Lead Capital Limited, 2008). However, several effects particularly from foreign agencies and governments are in place to improve the pharmaceutical industry in Nigeria.

However, it is necessary and logical to carry out a study on the performance in relation to the management of working capital of the Nigerian pharmaceutical companies. The rationale is to provide empirical evidences as to the effectiveness of the financial management of the pharmaceutical firms, in line with the effort of improving the sector. It is against this background that this study attempt to assess the impact of working capital management and the profitability of listed pharmaceutical firms in Nigeria.

\subsection{Objectives of the study}

i. To investigate the impact of receivables collection management on the profitability of listed pharmaceutical firms in Nigeria.

ii. To examine the impact of inventory management on the profitability of listed pharmaceutical firms in Nigeria.

\subsection{Research Hypotheses}

In line with the objectives of the study, the following hypotheses have been formulated:

$H_{01}$ : Receivables collection management has no significant impact on the profitability of the listed pharmaceutical firms in Nigeria.

$H_{02}$ : Accounts payable management has no significant impact on the profitability of listed pharmaceutical firms in Nigeria.

\section{Literature review}

\subsection{Accounts Receivables Management}

This constitutes that management of firms' debtors. Accounts receivables period is the average time taken by credit customers to settle their accounts. Van Horne (1981) states that, since the purpose of offering credit are to maximize profitability, the costs of debt collection should not be allowed to exceed the amounts recovered. More so, a company should prepare regularly aged trade receivables analysis and take steps to chase late payers. It is helpful to establish clear procedures for chasing late payers, to set out the circumstances under which credit control staff should send out reminders and initiate legal proceedings. Some thought could also be given to charging interest on overdue accounts to encourage timely payment, depending on the likely response of customers Van Horne and Wachowicz, (2004).

In managing operating liquidity, the receivables are a very important component of current assets and debtors collection period or receivables turnover in days is the average length of time required to convert the firm's receivables into cash (Raheman et al., 2011). They added that managerial efficiency in granting and controlling credit could be ascertained on the basis of receivables turnover in days. It would indicate the pattern of debtors on the basis of which liquidity of debtors could be ascertained. If the firm takes more time in collecting receivables, the profitability of the firm declines. 
To make a sensible decision about whether to trade with a company or not, information about the business is needed. The risk of bad debts can be minimized if the creditworthiness of new customers is carefully assessed before credit is granted and if the creditworthiness of existing customers is reviewed on a regular basis. Relevant information can be obtained from a variety of sources. New customers can be asked to provide bank references to confirm their financial standing, and trade references to indicate satisfactory conduct of business affairs (Padachi, 2006). Published information, such as the audited annual report and accounts of a prospective customer, may also provide a useful indication of creditworthiness. A company's own experience of similar companies will also be useful in forming a view on credit worthiness, as will the experience of other companies within a group.

For a fee, a report may be obtained from a credit reference agency, the credit report may include a company profile, recent accounts, financial ratios and industry comparisons, analysis of trading history, payment trends, types of borrowing, previous financial problems and a credit limit (Van Horne and Wachowicz, 2004). Bearing in mind the cost of assessing creditworthiness, the magnitude of likely regular sales could be used as a guide to determine the depth of the credit analysis.

Moreover, a company's credit management policy should help it maximize expected profits (Van Horne and Wachowicz, 2004). It will need to take into account its current and desired cash position, as well as its ability to satisfy expected demand. To put the credit management policy into effect successfully, managers and staff may need training or new staff may need to be recruited. Hence, the Key variables affecting the level of receivables will be the terms of sale prevailing in a company's area of business and the ability of the company to match and service comparable terms of sale. There is also a relationship between the level of receivables and a company's pricing policy: for example, it may choose to keep selling prices relatively high while offering attractive terms for early payment. The effectiveness of trade receivables follow-up procedures used will also influence the overall level of receivables and the likelihood of bad debts arising (Van Horne and Wachowicz, 2004).

\subsection{Accounts Payables Management}

The accounts or trade payables deferral period is the average time taken by a company to pay its trade payables, i.e. its suppliers (Uyar, 2009). Current liabilities include all obligations, which mature within a year such as creditors, bills payable, accrued expenses, short-term bank loan, income tax liability and long-term debt excluding bank overdraft, all of which quickly mature in the current year.

Uyar, (2009) opined that, accounts payables or Creditors Turnover ratio is used to know how much credit time received by the firm from its trade creditors. Creditors' turnover ratio shows the breathing time received by the firm in terms of payment of credit purchase. Hence, the effectiveness lies in whether the firm is enjoying the actual credit period promised by suppliers. It is calculated by dividing the amount of purchases by creditors. Here it has been assumed that all of the purchases have been made as credit purchases. The account payables period is computed by dividing account payables by net purchases multiplied by 365 days (Raheman et al., 2011).

\subsection{Operating Liquidity Policies}

Following the vital role operating liquidity management is playing; a company needs to formulate clear policies concerning the various components of operating liquidity. Key policy areas relate to the level of investment in working capital for a given level of operations and the extent to which operating liquidity is financed from short-term funds such as a bank overdraft (Uyar, 2009). A company should have working capital policies on the management of inventory, trade receivables, cash and short-term investments in order to minimize the possibility of illiquidity and inefficiency (Chittenden et al., 1998).

Nazir and Afza (2008) opined that Managers making decisions which are not in the best interests of the company; Examples of such suboptimal decisions are giving credit to customers who are unlikely to pay and ordering unnecessary inventories of raw materials. Sensible working capital policies will reflect corporate decisions on: the total investment needed in current assets, i.e. the overall level of investment; the amount of investment needed in each type of current asset, i.e. the mix of current assets; and the way in which current assets are to be financed. 
Operating liquidity policies need to consider the nature of the company's business since different businesses will have different working capital requirements (Chittenden et al., 1998). For instance, manufacturing company will need to invest heavily in spare parts and components and might be owed large amounts of money by its customers. A food retailer will have large inventories of goods for resale but will have very few trade receivables. The manufacturing company clearly has a need for a carefully thought out policy on receivables management, whereas the food retailer may not grant any credit at all. Operating liquidity policies will also need to reflect the credit policies of a company's close competitors, since it would be foolish to lose business because of an unfavorable comparison of terms of trade (Van Horne and Wachowicz, 2004). Any expected fluctuations in the supply of or demand for goods and services, for example due to seasonal variations in business, must also be considered, as must the impact of a company's manufacturing period on its current assets.

\subsection{Profitability}

According to Raheman et al. (2011) every business is most concerned with its profitability, they defined profitability as the ability to make profit from all the business activities of an organization, company, firm, or an enterprise. Additionally, it shows how efficiently the management can make profit by using all the resources available in the market. One of the most frequently used tools of financial ratio analysis is profitability ratios, which are used to determine the company's bottom line. Profitability in the words of Sohail et al. (2011) refers to the ability of a firm to earn returns on investment made in its assets that has a positive net present value. They further lament that a financial action that has a positive net present value will create wealth for shareholders and is therefore desirable. A financial action resulting in a negative net present value should be dropped because it will endanger shareholders' wealth. Hill et al. (2012) describes firm's profitability as the ability to generate revenue in excess of the cost of generating such revenue. Essentially, the term is a relative measurable in terms of profit and its relation with other elements that can directly influence the profit. However, profitability measures management efficiency in the use of organizational resources in adding value to the business. Kurawa (2011) further explains that, turnover in working capital variables will result in profit. The faster the turnover, the more the profit will grow. If the level or volume of current assets continues to grow, the associated costs will also grow and this will reduce the volume of profit. He further asserts that profitability can best be measured in term of Return on Assets, Returns on Equity as well as Returns on Capital Employed.

\subsection{Operating Liquidity and Firm Profitability}

Existing literature is strongly with the view that efficient operating liquidity improves profitability. In this context, profitability refers to the ability of an enterprise to generate profits from its investments; operating liquidity management affects profitability in several ways (Deloof, 2003). For instance, the management of cash, debtors and stocks affects the level of profits made by an enterprise. According to him, the excessive holding of stocks leads to high stock handling costs, deterioration in the value of stocks due to damage and obsolescence, theft or pilferage by employees and wastage. All these are cost to the firm which reduces its profitability. Moreover, inadequate stocks also lead to stock out costs and loss of goodwill of the firm, leading to losses or profits. Holding a high level of inventories leads to high capital tied up in stocks. This tied up capital means lost profitability due to forgone interest income which would have been earned if the capital tied up in stocks were invested (Saleemi, 2009).

Debtors' management policy adopted by a firm will also determine the cost of bad debts, debt administration, debt collection costs and the forgone benefits due to cash tied up in debtors. This may also include the cost of discounts which may be given to debtors to induce them to make prompt payments arising out of credit sales. Likewise all these costs will reduce the profitability of the firm (Manasseh, 2001).

Defective cash management will lead high costs associated with holding cash, financial distress and lost investment income due hold cash in a nonearning form (Manasseh, 2001). Examples of financial distress costs include interest costs, debt restructuring costs and legal costs. Likewise these costs will reduce the amounts of profits made by a firm. 


\section{Methodology of research}

This section centres on the methodology adopted in carrying out this study. It could be described as the road map that guides the direction to find answers to the stated research questions. The main issues discussed include research design, population and sample selection technique, data collection technique, data analysis technique as well as justification of the methods adopted.

\subsection{Research Design}

This research adopts correlational and ex-post facto designs. This ex-post facto research aims to study the impact of working capital management empirically on the profitability of pharmaceutical companies, while the correlational design is to explore the degree of association between all the variables under consideration. The choice of correlational research design in this study is informed by the fact that, the aim of the design is to investigate the relationships between variables and to estimate the impact of one the variable (independent variable) on another (dependent variable), so as to establish a causal relationship or otherwise among the variables. This is therefore consistent with the objective of the study.

\subsection{Population Sample of the Study}

The population of this study is all the nine pharmaceutical companies listed on the floor of Nigerian Stock Exchange as at 31st December, 2011 (See table 1). In selecting the sample size, the following criteria are adopted;

1) Their business activity is not of investment type (non-holding company).

2) The company is not suspended from the stock exchange during the period between 2002 and 2011.

Table 1. Listed Pharmaceutical Firms in Nigeria

\begin{tabular}{clc}
\hline S/N & \multicolumn{1}{c}{ Firms } & Sample Selected \\
\hline $\mathbf{1}$ & Ekocorps Plc & \\
$\mathbf{2}$ & Evans Medical Plc & Selected \\
$\mathbf{3}$ & Fidson Healthcare Plc & Selected \\
$\mathbf{4}$ & Glaxo Smithkline Plc & \\
$\mathbf{5}$ & May \& Baker Plc & Selected \\
$\mathbf{6}$ & Morison Industries Plc & \\
$\mathbf{7}$ & Neimeth International Pharma Plc & Selected \\
$\mathbf{8}$ & Pharma-Deke Plc & Selected \\
$\mathbf{9}$ & Union Diagnostic and Clinical Plc & \\
\hline
\end{tabular}

Source: Nigerian Stock Exchange Fact-book (2010-2011)

Based on the aforementioned criteria, only 5 pharmaceutical companies qualified to be members of the sample of this study.

\subsection{Method of Data Collection}

The study use secondary data from secondary sources, which is financial statements of all the sampled firms of the study, for the period of ten years $(2002-2011)$.

\subsection{Data Analysis}

Panel data was used in examining changes in variables over time and differences in variables between subjects. OLS regression technique is used in this study because of the effectiveness and efficiency of the technique in estimating the statistical relationship/impact of one variable on another variable. Hence, this is consistent with the objective of this study, investigating the impact of working capital management on the profitability of listed pharmaceutical firms in Nigeria.

In view of the panel nature of the data (cross-sectional and time series) for the study, the study employed different regression models, which include Ordinary Least Squares (OLS) Model, Fixed Effect (FE) Model and Random Effect (RE) Model. Appropriate tests such as Hausman Specification Test and Breusch and Pagan Lagrangian Multiplier Test for Random Effects are used to in arriving at the most suitable model 
for the study (OLS model). The study on the other hand conducted robustness tests to ensure the validity and fitness of the results. This includes test for Heteroskedasticity, Autocorrelation and Multicolinearity, this is an efforts to comply with the classical assumption of OLS and the model of the study in general. The analysis is conducted using STATA 10.1 version.

\section{Results}

The analyses and interpretations of the tests conducted on the data collected for the study are presented in this section.

Table 2. Descriptive Statistics of the Variables

\begin{tabular}{cccccccc}
\hline VARIABLES & Min & Max & Mean & SD & Skewness & Kurtosis & N \\
\hline GOP & 0.25 & 103.33 & 46.74 & 22.66 & 0.5810 & 2.6514 & 50 \\
ACR & 16 & 446 & 132.58 & 83.48 & 1.6682 & 6.4287 & 50 \\
ACP & 5 & 351 & 131.24 & 96.29 & 0.4004 & 1.9330 & 50
\end{tabular}

Source: STATA Output

Table 2 shows that our measure of profitability, gross operating profit (GOP) has a minimum value of 0.25 and 103.33 as the maximum value. The average value of the GOP is 46.74 with standard deviation of 22.66 , signifying that the data deviate from both side of the mean value by 22.66 . This implies that there is a wide dispersion of the data (profitability of listed pharmaceutical firms in Nigeria) from the mean, because of the large value of standard deviation which is closed to the mean. The kurtosis value of 2.6514 also suggests that majority of the data are higher than mean, as such the data did not meet the Gausian distribution assumption. Similarly, the coefficient of Skewness 0.5810 implies that the data is positively skewed, and thus, the data did not meet the symmetrical distribution assumption.

The results from the table also indicate that the minimum and maximum values of the account receivables (ACR) are 16 and 446 days respectively, with the mean value of 132.58 days and standard deviation of 83.48. This shows that the sample firms have an average of about 133 account receivables collection period, and the standard deviation value implies that there is dispersion from the mean value by 83.48 days in the sample firms. The coefficient of Skewness 1.6682 implies that the data is positively skewed, and thus, the data does not meet the symmetrical distribution assumption. On the other hand, the kurtosis value of 6.4287 also shows that most of the values are higher than the mean, and thus the data did not meet the Gausian distribution assumption.

The descriptive statistics from Table 2 shows that account payables (ACP) period has a minimum and maximum value of 5 and 351 days respectively. On average, the accounts payables period in the sample pharmaceutical firms is 131.24 days with standard deviation of 96.29 days. That is, the deviation from the mean is 96.29 days; the coefficient of Skewness 0.4004 implies that the data is positively skewed, and therefore did not conform to the symmetrical distribution requirement. Moreover, the coefficient of Kurtosis 1.9330 indicates that the ACP did not meet the Gausian distribution assumption.

Table 3. Results of Normality Test

\begin{tabular}{cccccc}
\hline VARIABLES & W & V & Z & Prob $>\mathbf{Z}$ & N \\
\hline GOP & 0.9390 & 2.868 & 2.247 & 0.0123 & 50 \\
ACR & 0.8551 & 6.813 & 4.092 & 0.0000 & 50 \\
ACP & 0.9259 & 3.484 & 2.662 & 0.0039 & 50
\end{tabular}

Source: STATA Output

The variables of the study are subjected to Shapiro-Wilk (W) test for data normality; the technique test the null hypothesis (that the data is normal), that is, the variable came from a normally distributed population. Table 4 indicates that the data for all the variables are not normally distributed, because the Pvalues are significant at $1 \%$ level of significance (ACR, ACP) and $5 \%$ level of significance.

\subsection{Inferential Statistics}

In this section, the results of the inferential statistics of the study is presented and discussed. The section covers correlation results and regression results of the model of the study, from which the research hypotheses are tested. 


\subsection{Correlation Results}

The summary of the Pearson correlation Coefficients of the variables of the study are presented in Table 4. as follows:

Table 4. Correlation Matrix of the Dependent and Independent Variables

\begin{tabular}{cccc}
\hline VARIABLES GOP ACR ACP & & & \\
\hline GOP & 1 & & \\
ACR & -0.3102 & 1 & \\
& $(0.0284)$ & & \\
ACP & 0.1113 & 0.0793 & 1 \\
& $(0.4416)$ & $(0.5842)$ & \\
\hline
\end{tabular}

P-Values in Parentheses

Source: STATA Output

Table 4 present the correlation results between operating liquidity (account receivables, account payables) and the profitability (gross operating profit) of the listed pharmaceutical firms in Nigeria. The table shows that there is a significant negative relationship between profitability (GOP) and account receivables days (ACR) from the correlation coefficient of -0.3102 , at $5 \%$ level of significance, ( $p$-value 0.0284 ). This result suggests that the more account receivables days remain outstanding in the sample pharmaceutical firms, profitability decreases. The result from the table indicates that there is a positive relationship between profitability (GOP) and account payables days (ACP) from the correlation coefficient of 0.1113 which is not significant at all levels of significance ( $p$-value of 0.4416 ). This implies that the more account payables remain outstanding in the sample pharmaceutical firms, profitability increases, but is not statistically significant.

\subsection{Results of Robustness Test}

In this section, the results of collinearity test and heteroskedasticity are presented and discussed, as shown by Table 4.5 as follows:

Table 5. Result of the Robustness Test of the Model of the Study

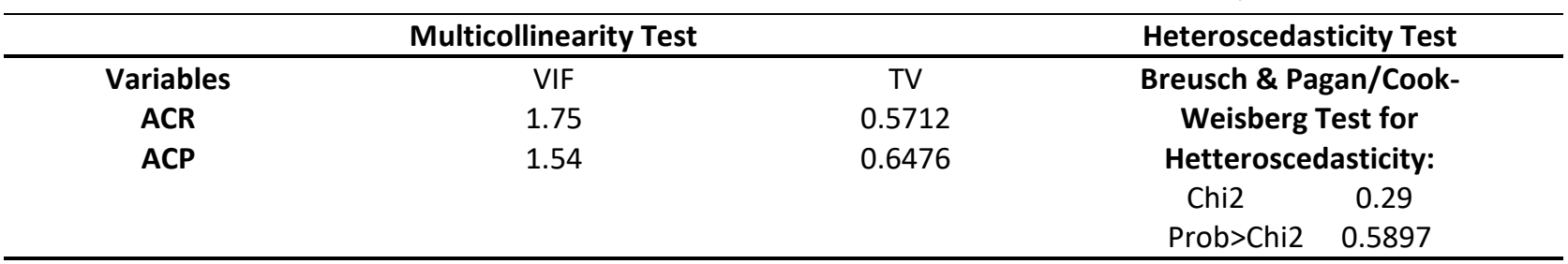

Source: STATA Output

The classical assumption of OLS regression model assumed that the error terms are normally distributed and independent (that is the error terms are uncorrelated); the explanatory variables are not perfectly correlated (absence of multicollinearity); the variance of the error terms is constant (Homoskedastic). When these assumptions have not been met, the estimators are biased and cannot be used in drawing any inference. However, the results from Table 5 proved the absence of perfect multicollinearity among the independent variables, because the smallest tolerance value (TV) is 0.3034 , corresponding with the highest variance inflation factor (VIF) of 3.30. The rule of thumb for the Tolerance Value is that any value of 0.1 and below implies the presence of perfect multicollinearity in the estimates, while for the Variance Inflation Factor a value of 10 and above is an indication of perfect multicollinearity.

The evidence from Breuch Pagan/Cook-Weisberg coefficient of 0.29 with $p$-value of 0.5897 confirms the absence of the effects of heteroskedasticity, that is, there is constant variance in the residuals. Moreover, Breuch Pagan/Cook-Weisberg test is also an evidence of the absence of serial correlation. Similarly, the panel is a micro-panel which the problem of autocorrelation is ineffective. Following the robustness of the results, OLS estimators are used in the test of hypotheses formulated in this study. 


\subsection{Hypotheses Testing}

In this section, the study tested the hypotheses formulated for the study; Table 6 presents the coefficients of the variables of the study from which the hypotheses are tested.

Table 6. Regression Coefficients of the Study

\begin{tabular}{ccccccc} 
& OLS Model & \multicolumn{6}{c}{ Fixed Effect Model } & \multicolumn{2}{c}{ Random Effect Model } \\
\cline { 2 - 7 } & Coef. & P-value & Coef. & P-value & Coef. & P-value \\
Variables & -0.1259 & 0.003 & -0.1394 & 0.004 & -0.1259 & 0.002 \\
ACR & 0.1283 & 0.000 & 0.1330 & 0.001 & 0.1283 & 0.000 \\
ACP & 57.2338 & 0.000 & 51.2316 & 0.000 & 57.2338 & 0.000 \\
CONSTANT & & & & & &
\end{tabular}

Source: STATA Output

The results in Table 6 shows that account receivables (ACR) days has a statistically significant negative impact on the profitability (GOP) of listed pharmaceutical firms in Nigeria as indicated by the coefficient of -0.1259 which is significant at $1 \%$ level of significance (P-value 0.003 ). That is, account receivable days significantly reduces the profitability of listed pharmaceutical firms in Nigeria. Based on this, the study rejects the null hypothesis one $\left(\mathrm{H}_{01}\right)$ which state that, Receivables collection has no significant impact on the profitability of the listed pharmaceutical firms in Nigeria. Therefore, the study infers that Receivables collection has significant impact on the profitability of the listed pharmaceutical firms in Nigeria, during the period covered by the study.

The table also shows that account payables (ACP) days has a significant positive effects on the profitability of listed pharmaceutical firms in Nigeria, considering the coefficient of 0.1283 which is significant at $1 \%$ level of significance ( $p$-value 0.000 ). That is, account payables day has significantly improved the profitability of listed pharmaceutical firms in Nigeria. Based on this, the study rejects the null hypothesis two $\left(\mathrm{H}_{02}\right)$ which states that account payables period has no significant impact on the profitability of the listed pharmaceutical firms in Nigeria. Therefore, the study infers that account payables period has significant positive impact on the profitability of listed pharmaceutical firms in Nigeria, during the period covered.

\section{Conclusions}

Based on the key findings of this research, the study concludes that a significant relationship exists between the operating liquidity components (account receivables and account payables) and the profitability of listed pharmaceutical firms in Nigeria. Specifically, the study concludes that, account receivables management has a statistical significant negative impact on the profitability of listed pharmaceutical firms in Nigeria. The study also concludes that account payables management has significant positive effects on the profitability of listed pharmaceutical firms in Nigeria.

\section{Recommendations}

In line with the findings and conclusions from this study, the study makes the following recommendations: The managers of Pharmaceutical firms in Nigeria should give due importance to working capital management, and emphasize an optimal working capital levels in their respective firms.

The managers of Pharmaceutical firms should decrease their days' inventory and days' accounts receivables cycle, by instituting adequate control and flexible credit policy. The managements of Pharmaceutical firms should employ experts in accounting and finance to help establish and monitor their required liquidity position through efficient working capital. The result suggest that pharmaceutical firms should keep optimum level of accounts receivable and cash conversion cycle to increase profitability. This could only be possible when pharmaceutical firms give due regard to every component of cash conversion cycle. 


\section{References}

1. Akinlo, O.O (2012). Determinants of working capital requirements in selected quoted companies in Nigeria. Journal of African Business, 13(1):40-50.

2. Burt, T. and Abbate, V. (2009). "Review on working capital management financial essay". Financial executive. Vol.25, issue 9, p. 54-56.

3. Chittenden, F., Poutziouris, P. and Michael, N. (1998). Financial management and working capital practices in UK SMEs. Manchester Business School, Manchester.

4. Deloof, M. (2003). Does working capital management affect profitability of Belgian firms, J. Business Finance and Accounting, V. 30. 573-588.

5. Deloof, M. and Jegers, M. (1996). Trade credit, product quality and intragroup trade: Some European Evidence. Financial Management, 25 (3), 945-968.

6. Jose, M. L., Lancaster, C. and Stevens, J. L. (1996). Corporate return and cash conversion cycle. Journal of economics and Finance, 20(1), 33-46.

7. Lead Capital Limited, (2008).

8. Manesse, T.S. (1994). The Cash Flow Timeline and the Credit Manager. Business Credit, July/August.

9. Raheman, A. \& Nasr, M. (2007), Working Capital management and profitability, case of Pakistani firms, International Review of Business Research papers, 3 (1), 279-300.

10.Rehn, E. (2012), Effect of Working Capital Management on Company Profitability, an industrywise study of Finnish and Swedish Public Companies, Department of Accounting Hensen School of Economics, Helsinki

11.Rahema, A., Qayyum, A. and Afza, T. (2011).Sector-wise Performance of Working Capital Management Measures and Profitability Using Ratio Analysis Interdisciplinary Journal of Contemporary Research in Business Vol. 3 (8).

12.Saalemi N. A., (2008/2009). Business Finance-Working capital management. East African Edition.

13.Stephen,K. K. (2012), Analysis of Effects of Working Capital Management on Profitability of Manufacturing Companies: A Case Study of Listed Manufacturing Companies on Nairobi Securities Exchange. A Research Project Submitted to the School of Business in Partial Fulfillment of the Requirements for the Award of a Master of Business Administration Degree (Finance Option) of Kabarak University.

14.Uyar, A. (2009). The Relationship of cash conversion cycle with firm size and profitability: An empirical investigation in Turkey. International Research Journal of Finance and Economics, 24: 186-193.

15.Vishnani, S. \& Shah, B. K. (2007). Impact of Working Capital Management Policies on Corporate Performance -An Empirical Study. Global Business Review, 8, 267.

16.Vineet, K. and Sukhdev, S. (2013) Managing Efficiency and Profitability through Working Capital: An Empirical Analysis of BSE 200 Companies Asian Journal of Business Management 5(2): 197-207, 2013.

17.Van Horne, J. C. \& Wachowicz, J. M. (2000). Fundamentals of financial management. Upper saddle River, New York: Prentice Hall International.

18.Van Horne, J. C, \& Wachowicz, J. M. (1998). Fundamentals of Financial Management, Prentice Hall, Englewood Cliffs, NJ.

19.Van Horne, J. C. (1981). Financial Management and Policy, Prentice Hall, Englewood Cliffs, NJ.

20.Vedavinayagan, G. (2007). An analysis of working capital management efficiency in telecommunication equipment industry, Rivier Academic Journal, 3(2). Retrieved from www.rivieracademicjournal.com.

21.Wang, Y. J. (2002). Liquidity management, operating performance and corporate value: Evidence from Japan and Taiwan. Journal of Multinational Financial Management. 12(2), 159-169. 